\title{
Editorial \\ Sustainable Steel Industry: Energy and Resource Efficiency, Low-Emissions and Carbon-Lean Production
}

\author{
Valentina Colla *(i) and Teresa Annunziata Branca \\ Scuola Superiore Sant'Anna, TeCIP Institute, Via Moruzzi 1, 56124 Pisa, Italy; teresa.branca@santannapisa.it \\ * Correspondence: valentina.colla@santannapisa.it; Tel.: +39-050882328
}

check for updates

Citation: Colla, V.; Branca, T.A. Sustainable Steel Industry: Energy and Resource Efficiency,

Low-Emissions and Carbon-Lean Production. Metals 2021, 11, 1469. https://doi.org/10.3390/met11091469

Received: 23 August 2021

Accepted: 10 September 2021

Published: 16 September 2021

Publisher's Note: MDPI stays neutral with regard to jurisdictional claims in published maps and institutional affiliations.

Copyright: (c) 2021 by the authors. Licensee MDPI, Basel, Switzerland. This article is an open access article distributed under the terms and conditions of the Creative Commons Attribution (CC BY) license (https:// creativecommons.org/licenses/by/ $4.0 /)$.
The three pillars of sustainability represented by the environment, economy and society in the steel manufacturing industry are directly connected to the efficient and effective management of resources, such as energy, raw materials, by-products and water. This can also be beneficial for the mitigation of $\mathrm{CO}_{2}$ emissions directly or indirectly associated with the steelmaking processes.

This Special Issue aims at covering a broad range of tools, technologies and experiences related to improving the sustainability of the steel production. In particular, this book collects seven manuscripts from academic and industrial researchers with stimulating new ideas and original results as well as three review papers.

Concerning the reduction of $\mathrm{CO}_{2}$ emissions, the optimal exploitation of process offgases, not only for energy production but also for their chemical content, can be beneficial. In [1], the target of reducing the $\mathrm{CO}_{2}$ emissions from the integrated steelmaking route is faced by valorizing the process off-gases as feedstock for methane and methanol syntheses through hydrogen enrichment. In particular, Zaccara et al. propose a comparative analysis of different hydrogen production processes exploiting renewable energy, namely polymer electrolyte membrane electrolysis, solid oxide electrolyze cell electrolysis, and biomass gasification. On the other hand, in [2], the issue of increasing the metallic iron input in the form of scrap within the integrated steelmaking route based on blast furnace $(\mathrm{BF})$ and basic oxygen furnace (BOF) is faced. The aim is to reduce the overall $\mathrm{CO}_{2}$ emissions connected to this process, as scrap is a renewable resource that can be recycled and only needs energy for being melted.

Relevant benefits can also be achieved through the implementation of novel technology for the replacement of fossil C-sources. Echterhof in [3] describes the use of carbon in Electric Arc Furnace (EAF)-based steelmaking and analyses the recent research on the use of alternative carbon sources, by providing an overview on the possibilities to substitute fossil charge or injection carbon by carbon-neutral biomass-based or waste-based materials.

A further very relevant aspect for improving sustainability of the steelmaking processes concerns the optimal valorization of by-products and residuals, from iron and steelmaking processes, which can be internally recycled and reused, due their content of valuable elements. Synergies with other sectors are being explored through the implementation of circular economy solutions to approach the "zero-waste" goal, by also promoting the use of by-products outside the steelmaking cycle, according to the concept of industrial symbiosis. On this topic, an interesting overview of the amounts of steelmaking residues generated in Europe is provided in [4] by Rieger et al., who also describe methods for circular economy approaches to close material cycles, create ideas for industrial symbiosis and increase the internal residues recycling within steelmaking processes.

In [5], Hledik et al. face the problem of finding the best solution for reusing the dust deriving from the so-called MEROS (maximized emission reduction of sintering) process developed by Siemens-VAI by characterizing sinter dusts from two different plants and by identifying the differences between various charges and plants, as knowledge on the dust ingredients is fundamental for assessing potential recycling or reuse options. 
Lundkvist et al., in [6,7], investigate the OXYFINES technique developed by Linde for upgrading fine particulate and zinc containing materials. In particular, in [6], the outcomes of pilot trials are presented and discussed, which assess the influence of different process parameters to the aim of developing an optimal concept for upgrading BF sludge by achieving a high degree of zinc separation from the sludge itself, and by generating an iron oxide product, suitable for the straightforward use within the steelmaking process. In [7], an overall system analysis is proposed by assessing advantages on the prospects of integrating an OXYFINES concept in an iron and steel production route.

Slag is the most relevant by-product of the steelworks and shows a strong potential for reuse and recycling inside and outside of the steel production cycle. In [8], Terrones-Saeta et al. analyze the benefits of incorporating ladle furnace slag as a filler in bituminous mixtures to be used for pavements in the construction sector. In [9], Teo et al. assess the recycling potential of EAF steel slag, with a particular focus on the Malaysian steel industry, and evaluate the different possible steel slag recycling options based on the engineering properties.

In [10], $\mathrm{Li}$ et al. propose a solution to increase the ratio of lump ore into the BF in order to reduce environmental impact and cost of the process, by analyzing the soft-melt dropping properties and primary-slag formation behaviors of the charge at increasing values the lump ore ratio as well as their internal relations and the mechanism. A largescale soft-melt dropping equipment is exploited to select different lump ore ratios and the chemical composition, slag phase composition and melting properties of the resulting primary slags is analyzed. The soft-melt dropping properties and primary-slag formation behaviors are also explored.

Finally, in [11], a systematic study on the specific heat capacity of the BF slag is proposed to establish the relationship between this fundamental attribute of this material and its chemical composition, with the final aim of analyzing the heat release behavior of BF slag during the cooling process in view of possible heat recovery.

Funding: This research received no external funding.

Acknowledgments: As Guest Editors, we want to express our gratitude to Melia Wang for her valuable and professional support and her active role in the publication. We gratefully thank the entire staff of the Metals Editorial Office for fruitful collaboration. Last but not least, we express our gratitude to all the contributing authors and reviewers, who allowed the production of this Special Issue.

Conflicts of Interest: The authors declare no conflict of interest.

\section{References}

1. Zaccara, A.; Petrucciani, A.; Matino, I.; Branca, T.A.; Dettori, S.; Iannino, V.; Colla, V.; Bampaou, M.; Panopoulos, K. Renewable Hydrogen Production Processes for the Off-Gas Valorization in Integrated Steelworks through Hydrogen Intensified Methane and Methanol Syntheses. Metals 2020, 10, 1535. [CrossRef]

2. Liu, Z.; Yu, Z.; She, X.; Tang, H.; Xue, Q. Numerical Investigation of Blast Furnace Operation with Scrap Charging. Metals 2020, 10, 1666. [CrossRef]

3. Echterhof, T. Review on the Use of Alternative Carbon Sources in EAF Steelmaking. Metals 2021, 11, 222. [CrossRef]

4. Rieger, J.; Colla, V.; Matino, I.; Branca, T.A.; Stubbe, G.; Panizza, A.; Brondi, C.; Falsafi, M.; Hage, J.; Wang, X.; et al. Residue Valorization in the Iron and Steel Industries: Sustainable Solutions for a Cleaner and More Competitive Future Europe. Metals 2021, 11, 1202. [CrossRef]

5. Hledik, C.; Goetz, M.; Ottner, F.; Fürhacker, M. MEROS Dust Quality of Different Plants and Its Potential Further Uses. Metals 2021, 11, 840. [CrossRef]

6. Lundkvist, K.; Rosendahl, S.; Nyman, F.; Bölke, K.; Gustavsson, L.; Söderström, D.; Wedholm, A. OXYFINES Technique for Upgrading Zinc Containing Blast Furnace Sludge-Part 1: Pilot Trials. Metals 2020, 10, 1468. [CrossRef]

7. Lundkvist, K.; Rosendahl, S.; Nyman, F.; Bölke, K.; Gustavsson, L.; Söderström, D.; Wedholm, A. OXYFINES Technique for Upgrading Zinc Containing Blast Furnace Sludge-Part 2: System Analysis. Metals 2020, 10, 1471. [CrossRef]

8. Terrones-Saeta, J.M.; Suárez-Macías, J.; Iglesias-Godino, F.J.; Corpas-Iglesias, F.A. Evaluation of the Physical, Chemical and Environmental Properties of Ladle Furnace Slag for Their Utilization as Filler in Bituminous Mixtures. Metals 2021, 11, 466. [CrossRef] 
9. Teo, P.T.; Zakaria, S.K.; Salleh, S.Z.; Taib, M.A.A.; Mohd Sharif, N.; Abu Seman, A.; Mohamed, J.J.; Yusoff, M.; Yusoff, A.H.; Mohamad, M.; et al. Assessment of Electric Arc Furnace (EAF) Steel Slag Waste's Recycling Options into Value Added Green Products: A Review. Metals 2020, 10, 1347. [CrossRef]

10. Li, Y.-F.; He, Z.-J.; Zhan, W.-L.; Kong, W.-G.; Han, P.; Zhang, J.-H.; Pang, Q.-H. Relationship and Mechanism Analysis of Soft-Melt Dropping Properties and Primary-Slag Formation Behaviors of the Mixed Burden in Increasing Lump Ore Ratio. Metals 2020, 10, 1254. [CrossRef]

11. Yang, Y.; Lei, T.; Qin, Y. Effect of MgO Content on Heat Capacity of Synthetic BF Slag and Heat Release Behavior during Cooling Process. Metals 2021, 11, 1294. [CrossRef] 